\title{
Quality of life, anxiety and depression in head and neck cancer patients: a randomized clinical trial*
}

\author{
Qualidade de vida, ansiedade e depressão de pacientes com câncer \\ de cabeça e pescoço: estudo clínico randomizado \\ Calidad de vida, ansiedad y depresión de pacientes con cáncer \\ de cabeza y cuello: estudio clínico randomizado
}

How to cite this article:

Hortense FTP, Bergerot CD, De Domenico EBL. Quality of life, anxiety and depression in head and neck cancer patients: a randomized clinical trial. Rev Esc Enferm USP. 2020;54:e03546. DOI: http://dx.doi.org/10.1590/S1980-220X2018040103546

\section{Flávia Tatiana Pedrolo Hortense \\ Cristiane Decat Bergerot ${ }^{2}$ \\ Edvane Birelo Lopes De Domenico ${ }^{1}$}

* Extracted from the thesis: "Educação para o autoregenciamento de pacientes com câncer de cabeça e pescoço apoiada em multimídia”, Escola Paulista de Enfermagem, Universidade Federal de São Paulo, 2017.

${ }^{1}$ Universidade Federal de São

Paulo, São Paulo, SP, Brazil.

${ }^{2}$ City of Hope Comprehensive Cancer Center, Duarte, CA, United States of America.

\begin{abstract}
Objective: To evaluate an educational program based on the principles of self-management with a conventional educational program through quality of life, anxiety and depression instruments within 12 months of starting cancer treatment. Method: An experimental, randomized, controlled study conducted with head and neck cancer patients treated at a university hospital in the city of São Paulo, Brazil. Patients were randomly divided into two groups: the control group submitted to the conventional educational plan, and the experimental group submitted to the educational plan for self-management. Descriptive and analytical statistics were used for the analyzes using the t-test, Fischer's exact test and Repeated Measures ANOVA. Results: Twenty (20) patients were selected. Most participants were male, in advanced stages of disease and undergoing three therapeutic modalities. The control group showed a gradual decrease in quality of life scores during treatment, while the experimental group progressively increased. The correlation was significant between the presence of anxiety and depression symptoms and poor quality of life. Patients in the control group had a significant worsening in social/family wellbeing $(\mathrm{P}=0.02)$ and the prevalence of additional head and neck cancer-related additional concerns $(\mathrm{P}=0.01)$, while the experimental group had reduced anxiety symptoms $(\mathrm{P}$ $=0.001)$ and improved emotional well-being $(\mathrm{P}=0.01)$. Conclusion: The educational intervention based on building self-management skills favored quality of life and reduced anxiety and depression. Brazilian Registry of Clinical Trials (RBR 2q53ct).
\end{abstract}

\section{DESCRIPTORS}

Head and Neck Neoplasms; Self Care; Health Education; Quality of Life; Anxiety; Oncology Nursing. Inhalation. 


\section{INTRODUCTION}

Head and neck cancer has a global impact of over 600,000 new cases each year. It is among the ten most frequent types of cancer in Brazil, affecting about $1.7 \%$ of the population ${ }^{(1)}$. Head and neck cancer includes malignant tumors of the upper aerodigestive tract, with $80 \%$ of the causes attributed to environmental influences, especially related to lifestyle, above all alcohol and tobacco consumption which are both well-established and preponderant etiological factors in patients with this condition ${ }^{(1)}$. Therapeutic interventions, alone or in combination, usually result in significant functional and aesthetic disabilities that impact quality of life (QoL) and biopsychosocial adaptation ${ }^{(1)}$.

Evidence suggests that providing information, knowledge and skills about treatment and its consequences makes the patient more active and participant, reduces the symptoms of anxiety and depression (AD), and also improves QoL ${ }^{(2)}$. Health education actions comprise teaching and learning practices developed in order to enable the individual to critically analyze their reality, stimulating the search for solutions and decision making for the problems experienced in the health-disease process ${ }^{(3)}$.

Among the current conceptions, self-management stands out as a strategic concept for educational actions aimed at building skills in patients, their families and/or caregivers to make decisions about different aspects of their illness condition in its chronicity, whether biological, psychosocial and/or spiritual, in a relationship of mutual respect and planning ${ }^{(4)}$. In a recent systematic review study, qualitative narrative synthesis suggested that self-management educational interventions improved symptoms of fatigue, pain, $\mathrm{AD}$, and emotional distress, and increased QoL perception in patients diagnosed with cancer ${ }^{(5)}$.

Self-management education should include teaching objectives that excel in making the patient able to handle the situations inherent in their diagnosis, treatment and rehabilitation $^{(6)}$. According to the intended learning objectives such as informing, knowing, generating skills and attitudes, single or combined strategies should be chosen, with the latter showing better results such as associations between verbal instructions, demonstrations and simulations, written materials (booklets/ leaflets), content through videos, and face-to-face multiprofessional consultations or by phone or website ${ }^{(4-6)}$.

Patients with head and neck cancer have extensive care demands in the first months of treatment as they are invariably undergoing major surgical recovery, with clinical procedures such as tracheostomies and enteral feeding by nasoenteric tube or gastrostomy, and presenting temporary or permanent functional losses. From this perspective, it is assumed that self-management education in the present investigation should aggregate strategies which associate the senses in a planned and intentional way through integrated multiprofessional consultation; this would involve the patient and family being able to converse with a physician and nurse in the same physical space, along with the availability of multimedia educational material (video and print), as well as simulation of procedures, so that patients could acquire knowledge, skills and attitudes and manage normal and risk situations arising from the disease process of cancer.
Thus, the following study question was defined: does exposure to an educational program based on self-management principles decrease $\mathrm{AD}$ levels and improve the QoL perception of these patients? Therefore, the objective was to comparatively evaluate an educational program based on self-management principles through QoL and AD instruments.

\section{METHOD}

\section{STUdPY DESIGN}

This is a 12 -month randomized controlled trial ${ }^{(7)}$ conducted in the city of São Paulo (SP, Brazil), at the Head and Neck Surgery Outpatient Clinic of the São Paulo Hospital of the Universidade Federal de São Paulo (HSP-Unifesp).

\section{Population}

The study population consisted of newly diagnosed patients with head and neck squamous cell carcinoma who began cancer treatment at the above-mentioned institution. The sample consisted of eligible patients between October 2015 and April 2016, and data were collected between October 2015 and April 2017. The following inclusion criteria were considered: age between 18 years and 80 years, newly diagnosed with malignant tumors of the upper aerodigestive tract, treated at the aforementioned outpatient clinic and submitted to the first line of cancer treatment. Patients who underwent treatment at another institution or who had a psychiatric disorder diagnosis documented in their medical record were excluded.

\section{Data collection}

Data collection was performed in 4 meetings. Data regarding the sociodemographic and clinical characteristics of each patient were collected in the initial evaluation (T0), such as: age, gender, marital status, education, income, diagnosis, risk factors, staging (clinical and pathological), and treatment. The Functional Assessment of Cancer Therapy - Head and Neck (FACT-H\&N) questionnaires were also applied to assess QoL, consisting of 38 items evaluating the following 5 domains: physical well-being ( 7 items), social/ family well-being ( 7 items), emotional well-being ( 6 items), functional well-being ( 7 items), and additional head and neck cancer-related additional concerns $\left(11\right.$ items ${ }^{(8)}$. These items have a 5-point Likert scale, ranging from not at all to very much. For correction and evaluation, the instrument is scored from 0 to 148 for the global scale and from 0 to 28 for the other subscales, with 0 to 24 for the emotional well-being scale. The higher the score, the better the $\mathrm{QoL}^{(8)}$.

The Hospital Anxiety and Depression Scale (HADS) was applied for the AD symptoms, consisting of 14 multiple-choice items, with 7 items focused on the evaluation of anxiety symptoms (HADS-A) and 7 on depressive symptoms (HADS-D). The score of each item ranges from 0 to 3 , with 21 being the maximum score in each subscale ${ }^{(9)}$. The score indicating anxiety is $\geq 8$ and the score for depression is $\geq 9^{(9)}$. The proposed educational activities were also performed at this time. 
QoL and $\mathrm{AD}$ were reevaluated at the follow-up meetings at 3 months (T1), 6 months (T2) and 12 months (T3). In each meeting, the researcher clarified how the different instruments should be completed, offering reading help to patients who had difficulties in understanding, without generating influence on their answers.

The educational action began in the first data collection (T1), lasting approximately 60 minutes for both the control (CG) and experimental (EG) groups. The main researcher participated in both the educational action and in the data collection, with the help of other nurses (nursing residents) and/or graduates trained to maintain uniform actions throughout the data collection.

The CG intervention consisted of individual medical and nursing consultations. Next, a demonstration on the use of artifacts (tracheostomy cannulas, feeding tubes and dressing materials) was performed on appropriate mannequins in an appropriate room. Educational leaflets were provided in the institution at the end, containing basic and general information about preoperative preparation, including guidelines for hospitalization and need for fasting, postoperative hygiene (body and oral) care, enteral feeding tube handling and tracheostomy cannula care. It is noteworthy that both patient and family education in the CG was characterized by an association of strategies such as separate multidisciplinary consultations, demonstrations of procedures and offering printed educational material, but without the educational objectives being outlined for self-management.

The educational intervention of the EG was composed of integrated medical and nursing consultations being held together with educational video exhibition, recorded in the amphitheater of the HSP-Unifesp Head and Neck Surgery Outpatient Clinic, and was attended by professionals of this unit (nurse, speech therapist, head and neck surgeon and nutritionist), totaling 7 video modules with a duration of $2 \mathrm{~min} 47 \mathrm{~s}$ to $11 \mathrm{~min} 91 \mathrm{~s}: 1)$ Introduction to what cancer is; 2) Surgical treatment guidelines; 3) Surgical treatment for oral cancer; 4) Surgical treatment for laryngeal cancer; 5) Hospital discharge and specific care at home with tracheostomy and feeding tubes; 6) head and neck radiotherapy; and 7) antineoplastic chemotherapy for head and neck cancer. After viewing the educational video, patients were invited to participate in a simulation on using the devices (tracheostomy cannulas, feeding tubes and dressing materials) on appropriate mannequins. The dialogue with the patient and their caregivers at this moment emphasized the main contents discussed in the video and the specific treatment to which the patient would be submitted, as well as sensitive listening and verbalizing any difficulties and concerns for managing the situations. At the end, they were then offered a digital versatile disc (DVD) containing the video displayed for home consultation, and a printed manual with the same information contained in the video.

The video and printed material contents were validated in a previous study, designed to meet the demands of this study(10), and are available on the website of the project's host educational institution, which can be accessed at: http://www.unifesp.br/campus/sao/epe4/ destaques/509-cancer-de-cabeca-e-pescoco-orientacoes.
The primary outcomes of the study were decreased $\mathrm{AD}$ levels and better perception of QoL.

The sample size was based on the average number of patients $(M=40)$ diagnosed with head and neck squamous cell carcinoma who started treatment at the HSP-Unifesp Head and Neck Surgery Outpatient Clinic in October 2015 to April 2016. The confidence interval was $95 \%$, standard deviation (SD) 0.5 and margin of error of $5 \%$. Patients were randomized by a random selection of $1: 1$, with the first patient directed to the CG, the second to the EG, and so on ${ }^{(7)}$.

\section{DATA ANALYSIS AND PROCESSING}

Descriptive analysis was used for data evaluation to assess the frequency, mean and standard deviation of sociodemographic and clinical variables. The t-test and Fischer's exact test were used for the homogeneity of the groups. The QoL and AD scores obtained at all assessment times were compared using the t-test and the correlation between the instruments was obtained by group and by time. Statistical significance was determined based on an alpha of 0.05 . Next, repeated measures ANOVA (RM-ANOVA) was used to verify the variance/covariance matrix of the data for significant interactions between the analyzed variables. All analyzes were performed using SPSS software, version 23.0.

\section{ETHICAL ASPECTS}

The project was submitted and approved by the Research Ethics Committee of UNIFESP, under number 554.220/2014, and registered in the Brazilian Registry of Clinical Trials (RBR 2q53ct). All participants who agreed to participate signed the Informed Consent Form according to Resolution 466/12 of the National Health Council ${ }^{(11)}$.

\section{RESULTS}

The outpatient clinic attended 40 new patients during the 6-month period for inclusion of patients in the sample, and 20 patients were selected according to the established eligibility criteria. Thus, 10 patients were included in the $\mathrm{CG}$ and 10 in the EG. There was a sample loss of 3 patients over the data collection months of the study by death, and therefore 9 patients from the CG and 8 from EG completed all the proposed evaluation times (Figure 1).

Regarding the sample characteristics, the average age in the $\mathrm{CG}$ was 50.4 years (SD = 13.3), $80 \%$ were male, $70 \%$ were married and $60 \%$ had up to 9 years of study. Most reported having some occupation (60\%), 11.1\% were retired, $80 \%$ were smokers and $60 \%$ were alcoholics. All participants followed some religion, half of them Catholic. Meanwhile, the average age in the $\mathrm{EG}$ was 58.8 years $(\mathrm{SD}=11.6), 70 \%$ were male, $60 \%$ were not married, $60 \%$ had completed up to 9 years of studying, $60 \%$ had no occupation, $25 \%$ were retired, 60\% were Catholic, 60\% were smokers and 40\% were alcoholics. All patients belonged to economic class $\mathrm{C}$, with a predominance of $\mathrm{C} 2$, which represents an average monthly household income of $\mathrm{R} \$ 1,625 \cdot 00^{(12)}$. No significant differences were observed between the CG and EG for sociodemographic variables. 


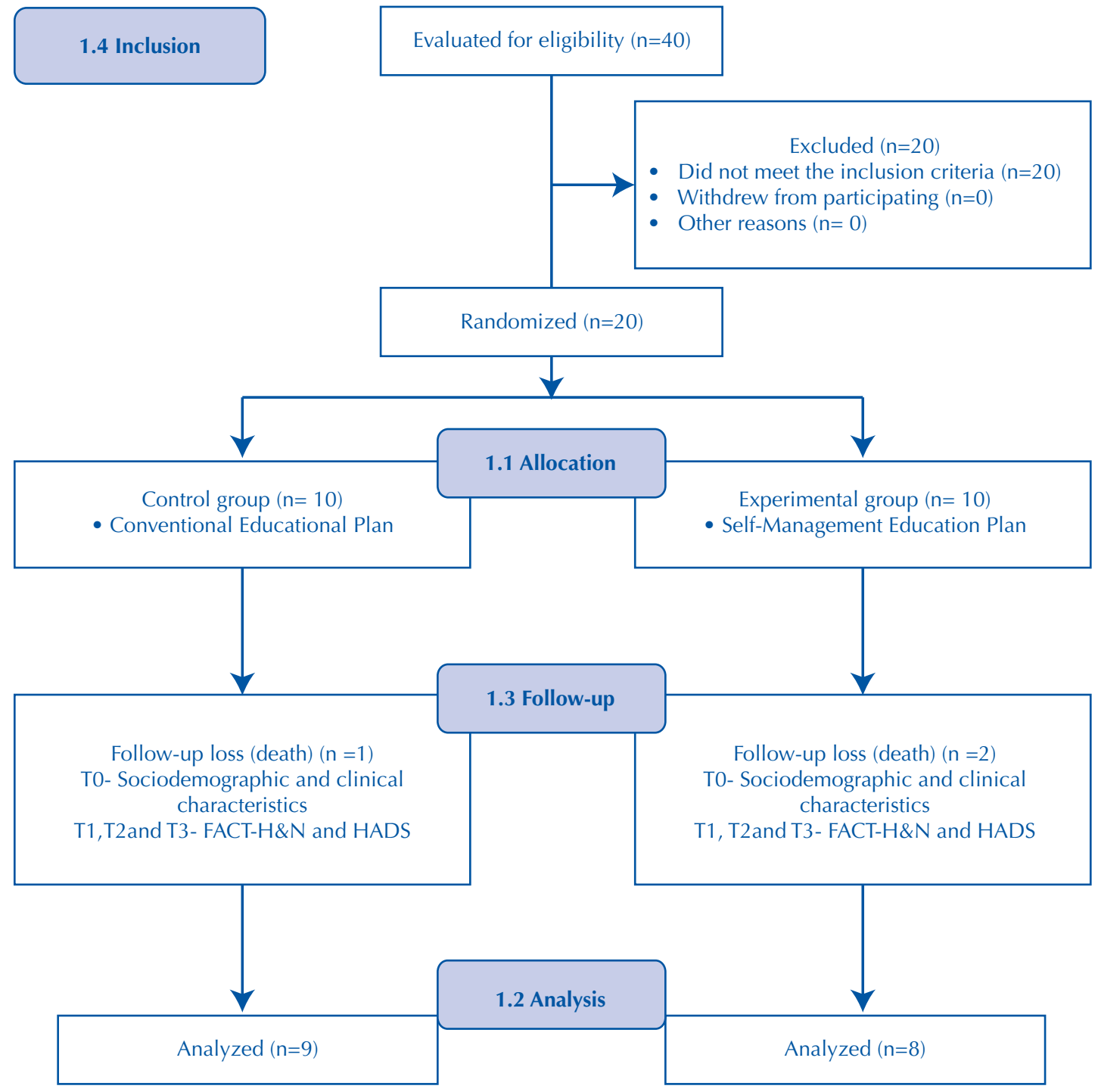

Figure 1 - CONSORT 2010 flowchart with final data collection data - São Paulo, SP, Brazil, 2017.

FACT-H\&N: Functional Assessment of Cancer Therapy - Head and Neck; HADS: Hospital Anxiety and Depression Scale.

Regarding the sample characteristics, the average age in the $\mathrm{CG}$ was 50.4 years $(\mathrm{SD}=13.3), 80 \%$ were male, $70 \%$ were married and $60 \%$ had up to 9 years of study. Most reported having some occupation $(60 \%), 11.1 \%$ were retired, $80 \%$ were smokers and $60 \%$ were alcoholics. All participants followed some religion, half of them Catholic. Meanwhile, the average age in the $\mathrm{EG}$ was 58.8 years $(\mathrm{SD}=11.6), 70 \%$ were male, $60 \%$ were not married, $60 \%$ had completed up to 9 years of studying, $60 \%$ had no occupation, $25 \%$ were retired, $60 \%$ were Catholic, $60 \%$ were smokers and $40 \%$ were alcoholics. All patients belonged to economic class $\mathrm{C}$, with a predominance of $\mathrm{C} 2$, which represents an average monthly household income of $\mathrm{R} \$ 1,625.00^{(12)}$. No significant differences were observed between the CG and EG for sociodemographic variables.

Cancer was located in the oral cavity in $60 \%$ of the CG cases, and $80 \%$ of patients were diagnosed at advanced stages (III and IV). The predominant treatment (70\%) was combined treatment (surgery + radiotherapy + chemotherapy).
In the EG, $60 \%$ of the tumors were also located in the oral cavity, $60 \%$ of which were diagnosed as late stage (III-IV). Among the therapeutic modalities, $30 \%$ were submitted to surgery and another $30 \%$ to combined treatment (surgery + radiotherapy + chemotherapy). Despite the differences found, they were not statistically significant.

A significant difference was found in the total QoL score in the descriptive analysis of the FACT-H\&N, considering the interaction groups and times. The $\mathrm{CG}$ score at $\mathrm{T} 0$ was higher than that reported by the EG. However, this correlation was not maintained until the end of follow-up. Moreover, there was no significant difference for the other subscales, considering the interaction groups and times, as presented in Table 1.

A similar analysis was done for HADS, however no significant difference was found between the evaluated groups. Overall, the CG patients reported a higher mean AD in T3 when compared to the EG (Table 2). 
Table 1 - Descriptive analysis of the FACT-H\&N quality of life instrument compared by group and by evaluation time - São Paulo, SP, Brazil, 2017.

\begin{tabular}{|c|c|c|c|c|c|c|}
\hline & Factor & T0* & $\mathrm{T} 1 *$ & T2* & T3* & P-value \\
\hline \multirow{2}{*}{ FACT-H\&N } & Control Mean (SD) & $112(14.7)$ & $100.3(23.1)$ & $94.7(19.2)$ & $101.9(24)$ & \multirow{2}{*}{$0.0012+$} \\
\hline & Experimental Mean (SD) & $96.4(8.1)$ & $105.9(17.7)$ & $106.4(10.4)$ & $112.3(10.4)$ & \\
\hline \multirow{2}{*}{ Physical well-being } & Control Mean (SD) & $24.5(93.2)$ & $21.1(6.1)$ & $20.3(5)$ & $22.7(4.3)$ & \multirow{2}{*}{0.1098} \\
\hline & Experimental Mean (SD) & $22.7(5.1)$ & $22.5(3.6)$ & $24.1(2.8)$ & $25.7(2.8)$ & \\
\hline \multirow{2}{*}{ Social/family well-being } & Control Mean (SD) & $23.6(9.2)$ & $19.7(6.2)$ & $17.8(5.2)$ & $17.9(6.9)$ & \multirow{2}{*}{0.0600} \\
\hline & Experimental Mean (SD) & $18.3(5.3)$ & $20.8(5.3)$ & $19.1(3.5)$ & $19.8(3.4)$ & \\
\hline \multirow{2}{*}{ Emotional well-being } & Control Mean (SD) & $18.6(4.7)$ & $19.3(4.9)$ & $18.3(4.2)$ & $19.4(4.7)$ & \multirow{2}{*}{0.6600} \\
\hline & Experimental Mean (SD) & $18.0(4.5)$ & $20.1(3.6)$ & $19.7(3.0)$ & $21.5(1.3)$ & \\
\hline \multirow{2}{*}{ Functional well-being } & Control Mean (SD) & $18.5(3.6)$ & $16.3(6.0)$ & $16.0(4.4)$ & $18.2(5.9)$ & \multirow{2}{*}{0.0532} \\
\hline & Experimental Mean (SD) & $15.2(2.3)$ & $17.1(4.3)$ & $18.4(2.8)$ & $19.1(1.7)$ & \\
\hline Additional concerns & Experimental Mean (SD) & $25.5(3.6)$ & $26.1(5.4)$ & $26.8(5.5)$ & $27.3(6.28)$ & 0.2408 \\
\hline
\end{tabular}

SD: standard deviation; FACT-H\&N: Functional Assessment of Cancer Therapy-Head and Neck.

* Months after starting cancer treatment: T0 = pre-treatment, T1 = 3 months, T2 = 6 months and T3 = 12 months.

+ Statistically significant difference for $\mathrm{P} \leq 0.05$.

Score: physical well-being (0-28), social/family well-being (0-28), emotional well-being (0-24), functional well-being (0-28), additional concerns (0-40), with a total score of $0-148$.

Table 2 - Descriptive analysis of the HADS anxiety and depression instrument compared by group and by evaluation time - São Paulo, SP, Brazil, 2017.

\begin{tabular}{|c|c|c|c|c|c|c|}
\hline & Factor & то* & T1* & T2* & T3* & P-value \\
\hline \multirow{2}{*}{ Anxiety } & Control Mean (SD) & $4.2(3.1)$ & $4(3.9)$ & $3.2(3.3)$ & $4.1(4.7)$ & \multirow{2}{*}{0.4667} \\
\hline & Experimental Mean (SD) & $4.6(4.3)$ & $3.9(3.1)$ & $3(2.2)$ & $2(1.3)$ & \\
\hline \multirow{2}{*}{ Depression } & Control Mean (SD) & $1.6(2.6)$ & $3.6(3.8)$ & $2.7(1.5)$ & $3(2.9)$ & \multirow{2}{*}{0.1374} \\
\hline & Experimental Mean (SD) & $3.6(3.4)$ & $2.7(3.1)$ & $2.5(2)$ & $1.6(1.3)$ & \\
\hline \multirow{2}{*}{ Total score } & Control Mean (SD) & $5.8(5.2)$ & $7.6(7)$ & $5.9(4.6)$ & $7.1(7)$ & \multirow{2}{*}{0.0600} \\
\hline & Experimental Mean (SD) & $8.2(7.1)$ & $6.6(5.8)$ & $5.5(4.1)$ & $3.6(2.4)$ & \\
\hline
\end{tabular}

SD: standard deviation; HADS: Hospital Anxiety and Depression Scale.

*Months after starting cancer treatment: T0 = pre-treatment, $\mathrm{T} 1=3$ months, $\mathrm{T} 2=6$ months and T3 = 12 months.

Score indicative of anxiety $\geq 8$, score indicative of depression $\geq 9$ and total score $=42$.

A significant inverse correlation was observed between the FACT-H\&N and HADS, indicating a relationship between higher AD scores and worse QoL scores. This correlation was obtained at $\mathrm{T} 0, \mathrm{~T} 1, \mathrm{~T} 2$ and $\mathrm{T} 3$ evaluation times for the $\mathrm{CG}$, and at $\mathrm{T} 0, \mathrm{~T} 1$ and $\mathrm{T} 2$ times for the $\mathrm{EG}$. An inverse correlation was found for the emotional well-being $(\mathrm{P}=0.0003)$ and the overall score domains of the FACT-H\&N score at T0 $(\mathrm{P}=0.0057)$. No correlation was found between $\mathrm{AD}$ in the other domains of the instrument. Low scores in the social/family well-being $(\mathrm{P}=0.0261)$ and emotional well-being $(\mathrm{P}=0.0009)$ domains were also associated with $\mathrm{AD}$ symptoms in the EG. The correlation was not significant for the other domains.

At T1, a similar result was found for low scores in the physical well-being $(\mathrm{P}=0.0063)$, emotional well-being $(\mathrm{P}$ $=0.0233)$, functional well-being $(\mathrm{P}=0.0025)$ domains and FACT-H\&N $(\mathrm{P}=0.0420)$ associated with the presence of $\mathrm{AD}$ symptoms in the CG. The same occurred in the EG, with low scores on the social/family well-being $(\mathrm{P}=$ 0.0070), emotional well-being $(P=0.0000)$, functional well-being $(P=0.0070)$, additional concerns $(P=0.0498)$ and FACT-H\&N $(\mathrm{P}=0.0003)$ associated with the presence of $\mathrm{AD}$ symptoms. At $\mathrm{T} 2$, low scores were again found in the physical well-being $(\mathrm{P}=0.0246)$, emotional well-being $(\mathrm{P}$ $=0.0087)$, functional well-being $(\mathrm{P}=0.0053)$ and FACT $\mathrm{H} \& \mathrm{~N}(\mathrm{P}=0.0051)$ associated with worse $\mathrm{AD}$ symptoms in the CG. An inverse association remained between $\mathrm{AD}$ symptoms and low scores in the EG in physical well-being $(\mathrm{P}=0.0206)$, emotional well-being $(\mathrm{P}=0.0309)$, functional well-being $(\mathrm{P}=0.0002)$, additional concerns $(\mathrm{P}=0.0453)$ and FACT-H\&N $(\mathrm{P}=0.0015)$. At the last assessment time $\left(\mathrm{T}_{3}\right)$, low scores in physical well-being $(\mathrm{P}=0.0013)$, social/ family well-being $(\mathrm{P}=0.0204)$, emotional well-being $(\mathrm{P}$ $=0.0000)$, functional well-being $(\mathrm{P}=0.0055)$ scales and FACT-H\&N ( $\mathrm{P}=0.0008)$ were associated with $\mathrm{AD}$ symptoms in the CG. No correlation was found in the EG.

When verifying the RM-ANOVA, the GreenhouseGeisser test in the CG indicated significant effect for worsening social/family well-being $(\mathrm{P}=0.02)$ and additional concerns $(\mathrm{P}=0.01)$ over the evaluation times. Other scales had no significant effect between the evaluation times. However, the same test indicated a significant effect to reduce the prevalence of anxiety $(\mathrm{P}=0.001)$ and better emotional well-being $(\mathrm{P}=0.01)$ in the EG over time. Other subscales showed no significant effect between the evaluation times. 


\section{DISCUSSION}

The sociodemographic and clinical characteristics of the evaluated population are in accordance with the characteristics described in the national records, mostly being male in their 50's or 60's, which corroborates the data found in the literature ${ }^{(13)}$. Most participants were married and this data is relevant from the perspective of care assistance and affective support. It is known that the family participates in the disease process and its dynamics change according to the demands of the disease, treatment and hospitalization. Knowing the family composition and structure, the roles played by its members and their availability for care is essential for structuring educational actions ${ }^{(14)}$.

Most of the sample had low education. Low education may directly reflect the lack of access to health services and difficulties in understanding information, guidance and recommendations related to health care. In this sense, patients become more vulnerable to risk factors for comorbidities and mortality and low healthcare standards ${ }^{(15)}$. In addition, most were classified with monthly household income corresponding to $\mathrm{R} \$ 1,625.00^{(12)}$ (approximately US $\$ 433.33$ at the current commercial dollar rate). Although the CG had a higher percentage of professionally active patients, the EG had a higher percentage of retirees, which may explain that both had similar financial conditions according to the economic classification used. The findings characterize the financial vulnerability of both groups, as well as reinforce the condition as a risk factor for head and neck cancer ${ }^{(15-16)}$.

This scenario expresses the importance of multidisciplinary care, which is fundamental to assist in meeting the biological, social, economic and psychological demands of patients and their families, with a view to adopting adaptive, safe and proactive behaviors, as well as access to social programs which economically contribute to the patient and family ${ }^{(15)}$. Notably, the illness process and the cancer diagnosis impact different areas of life of patients and their families, which may result in feelings of fear, insecurity, worry, hopelessness and loss; conditions which were observed in the present investigation. In this context, adopting a religion, which was unanimous among the participants, can be used as a resource to cope with illness and help in adapting to the demands imposed by the disease and treatment $t^{(15-17)}$.

A high prevalence of smoking and alcohol use by patients in both groups was identified. Tobacco use can be understood as a sociocultural issue and smoking and alcohol are used by some users as strategies to deal with or avoid negative feelings such as fear, worry, anger and sadness ${ }^{(18)}$.

The clinical data of the patients in this study ratify those described in the literature, confirming that it is a high risk population. In view of this finding, appropriate measures need to be developed to change the reality of late diagnoses in Brazil, optimizing the interval between symptom onset and diagnosis ${ }^{(16)}$. Thus, educational actions need to be proposed in the phase prior to clinical diagnosis, helping the population to identify symptoms and seek adequate care in the initial signs and symptoms.
The findings of the present investigation reinforce the importance of planned and intentional educational action for a comprehensive approach of cancer patients. Oncology education must be efficient enough to generate behaviors and attitudes for cancer prevention, early detection and, in the course of illness, to also generate self-management skills ${ }^{(4)}$.

Returning to the findings, the variations in QoL perceptions with lower scores at T2 and T3 treatment times are justified by the complexity of interventions such as extensive surgery and combined antineoplastic therapy, associated with chemotherapy and radiotherapy. Previous studies have shown the relationship between advanced tumors, extensive surgical resection, postoperative irradiation and worse $\mathrm{QoL}$ scores $^{(2,19)}$.

There was a favorable adaptive process to better $\mathrm{QoL}$ perception over time in the present study, with a slight and progressive increase in the other evaluation times. The design of the EG educational intervention with integrated medical and nursing consultations and screening the educational video based on the intentionality of building self-management skills, and the subsequent care simulation with devices and provision of educational material both corresponding to the video were certainly a collaborative factor, since the association of teaching strategies, repeating and reinforcing knowledge, skills and attitudes in a coherent and articulated way for patient autonomy and empowerment is at the heart of self-management education action.

The decrease in the social/family well-being domain was gradual over the evaluation times in the CG and EG, suggesting a possible communication difficulty between the patient, the family member and/or the caregiver. The past history of family relationship, the sequelae of treatment, and the probable distress in the relationship between patient and family may justify this result. Family members are the main source of social and emotional support for patients, playing an important role in managing the consequences of the illness process ${ }^{(19)}$. Possible previous relationship problems may be linked to dependence on alcohol, especially tobacco and other illicit drugs. Under these conditions, the patient and family-centered approach to care can help in the recovery of affective bonds, enable reconciliation, as well as protect family members/caregivers from negative emotional overload $^{(18-21)}$.

Regarding the AD symptoms, the period close to diagnosis and therapeutic decision was more favorable for the presence of anxiety symptoms in the CG and EG. The average reported by the patients in the other evaluation times in both groups was close to that described in the literature ${ }^{(22)}$. This equivalence and non-variation in the study times may come from interventions and referrals proposed by the team. As this study was conducted in the "real world", patients were instructed to talk to members of the medical team whenever they had clinical $\mathrm{AD}$ symptoms. In addition, the presence of $\mathrm{AD}$ symptoms was associated with worse $\mathrm{QoL}$ at all evaluation times.

It is noteworthy that these symptoms tend to worsen when $\mathrm{AD}$ is not treated, impairing (for example) adherence to treatment, favoring readmission to the health service, 
prolonging rehabilitation and not invariably resulting in reduced survival time ${ }^{(23)}$. The patient monitoring actions performed in the EG in the present investigation were easy to perform and feasible. The dialogue, based on the contents of the educational materials and the use of an appropriate instrument, helped and enabled the team in diagnosing and defining treatments for AD.

The results obtained from the research reinforce the presupposition that the educational action must be scientifically grounded and delineated to meet the demands of patients and their families with multiple interventions, which should be systematically evaluated once undertaken with indicators which signal their effectiveness and efficiency.

The limitations of the present study are concentrated in the small sample size caused by the decrease in the number of patients treated at the institution, which made some statistical analyzes unfeasible. Despite this limitation, it is believed that the different criteria adopted for evaluating the educational material were sufficient to indicate and highlight the benefit and quality of the intervention.

\section{CONCLUSION}

The educational intervention may have interfered in the gradual increase of FACT-H\&N scores during the course of treatment, reinforcing the benefit of the educational action, suggesting greater adaptability to the treatment, knowledge and skills developed to identify disease progression and adverse symptoms, in addition to strategies for resolving or minimizing these symptoms.

There was a reduction in anxiety symptoms and better emotional well-being in the EG in the longitudinal analysis of QoL and AD. Moreover, it was possible to attest to an unsatisfactory result in the CG, with worsening social/ family well-being and a greater presence of additional disease-related concerns.

It is expected that the results found in this experiment may motivate professionals and favor an analysis of the direct and indirect benefits of implementing an educational, multimedia, structured program based on the principles of self-management and existing $\mathrm{QOL}$ and AD measurement protocols in the cancer illness period.

\section{RESUMO}

Objetivo: Avaliar um programa educativo baseado nos princípios do autogerenciamento com programa educativo convencional, por meio de instrumentos de qualidade de vida, ansiedade e depressão em período de 12 meses transcorridos do início do tratamento. Método: Estudo experimental, randomizado, controlado, realizado com pacientes com câncer de cabeça e pescoço, tratados em hospital universitário do município de São Paulo. Os pacientes foram divididos aleatoriamente em dois grupos: grupo controle, submetido ao plano educativo convencional, e grupo experimento, submetido ao plano educativo para o autogerenciamento. Para as análises empregaram-se estatísticas descritiva e analítica, utilizando-se o teste t, o teste exato de Fischer e ANOVA de Medidas Repetidas. Resultados: Foram selecionados 20 pacientes. A maioria dos participantes foi do sexo masculino, em estádios avançados de doença e submetidos a três modalidades terapêuticas. $\mathrm{O}$ grupo controle apresentou queda gradual dos escores de qualidade de vida no transcorrer do tratamento, enquanto o grupo experimento aumentou progressivamente. A correlação foi significativa entre a presença de sintomas de ansiedade e depressão e baixa qualidade de vida. Pacientes do grupo controle apresentaram piora significativa do bem-estar social/ familiar $(P=0,02)$ e da prevalência de preocupações adicionais relacionadas ao câncer de cabeça e pescoço $(P=0,01)$, enquanto o grupo experimento apresentou redução dos sintomas de ansiedade $(\mathrm{P}=0,001)$ e melhora do bem-estar emocional $(\mathrm{P}=0,01)$. Conclusão: A intervenção educativa pautada na construção de habilidades para o autogerenciamento favoreceu a qualidade de vida e reduziu a ansiedade e a depressão. Registro Brasileiro de Ensaios Clínicos (RBR 2q53ct).

\section{DESCRITORES}

Neoplasias de Cabeça e Pescoço; Autocuidado; Educação em Saúde; Qualidade de Vida; Ansiedade; Enfermagem Oncológica.

\section{RESUMEN}

Objetivo: Evaluar un programa educativo basado en los principios de la autogestión con programa educativo convencional, mediante instrumentos de calidad de vida, ansiedad y depresión en período de 12 meses transcurridos desde el inicio del tratamiento. Método: Estudio experimental, randomizado controlado, llevado a cabo con pacientes con cáncer de cabeza y cuello, tratados en hospital universitario del municipio de São Paulo. Los pacientes fueron divididos aleatoriamente en dos grupos: grupo control, sometido al plan educativo convencional, y grupo experimento, sometido al plan educativo para la autogestión. Para los análisis se empleó estadística descriptiva y analítica, utilizándose la prueba t, la prueba exacta de Fischer y ANOVA de Medidas Repetidas. Resultados: Fueron seleccionados 20 pacientes. La mayoría de los participantes fue del sexo masculino, en estadíos avanzados de enfermedad y sometidos a tres modalidades terapéuticas. El grupo control presentó caída gradual de los scores de calidad de vida en el trascurso del tratamiento, mientras que el grupo experimento incrementó progresivamente. La correlación fue significativa entre la presencia de síntomas de ansiedad y depresión y la baja calidad de vida. Pacientes del grupo control presentaron empeoramiento significativo del bienestar social/ familiar $(\mathrm{P}=0,02)$ y de la prevalencia de preocupaciones adicionales relacionadas con el cáncer de cabeza y cuello $(\mathrm{P}=0,01)$, mientras que el grupo experimento presentó reducción de los síntomas de ansiedad $(\mathrm{P}=0,001)$ y mejora del bienestar emotivo $(\mathrm{P}=0,01)$. Conclusión: La intervención educativa basada en la construcción de habilidades para la autogestión favoreció la calidad de vida y redujo la ansiedad y la depresión. Registro Brasileño de Ensayos Clínicos (RBR 2q53ct).

\section{DESCRIPTORES}

Neoplasias de Cabeza y Cuello; Autocuidado; Educación en Salud; Calidad de Vida; Ansiedad; Enfermería Oncológica.

\section{REFERENCES}

1. Brasil. Ministério da Saúde; Instituto Nacional de Câncer José Alencar Gomes da Silva. Estimativa 2018: incidência de câncer no Brasil [Internet]. Rio de Janeiro: INCA; 2017 [citado 2018 jul. 05]. Disponível em: https://www.inca.gov.br/publicacoes/livros/estimativa-2018incidencia-de-cancer-no-brasil

2. Schulman-Green D, Jaser S, Martin F, Alonzo A, Grey M, McCorkle R, et al. Processes of self-management in chronic illness. J Nurs Scholarsh. 2012;44(2):136-44. DOI: http://dx.doi.org/10.1111/j.1547-5069.2012.01444.x 
3. Malta DC, Neto OLM, Silva MMA, Rocha D, Castro AM, Reis AAC, et al. National Health Promotion Policy (PNPS): chapters of a journey still under construction. Ciênc Saúde Coletiva. 2016;21(6):1683-94. DOI: http://dx.doi.org/10.1590/1413-81232015216.07572016

4. McCorkle R, Ercolano E, Lazenby M, Schulman-Green D, Schilling LS, Lorig K, et al. Self-management: enabling and empowering patients living with cancer as a chronic illness. CA Cancer J Clin. 2011;61(1):50-62. DOI: http://dx.doi.org/10.3322/caac.20093

5. Howell D, Harth T, Brown J, Bennett C, Boyko S. Self-management education interventions for patients with cancer: a systematic review. Support Care Cancer 2017;25(4):1323-55. DOI: https://doi.org/10.1007/s00520-016-3500-z

6. Leppla L, De Geest S, Fierz K, Deschler-Baier B, Koller A. An oral care self-management support protocol (OrCaSS) to reduce oral mucositis in hospitalized patients with acute myeloid leukemia and allogeneic hematopoietic stem cell transplantation: a randomized controlled pilot study Support Care Cancer. 2016;24(2):773-82. DOI: https://doi.org/10.1007/s00520-015-2843-1

7. Polit DF, Beck CT. Fundamentos da pesquisa em enfermagem: avaliação de evidências para a prática de enfermagem. 7a ed. Porto Alegre: ArtMed; 2011.

8. Vartanian JG, Carvalho AL, Furia CL, Castro Junior G, Rocha CN, Sinitcovisky IM, et al. Questionários para a avaliação de Qualidade de Vida em pacientes com câncer de cabeça e pescoço validados no Brasil. Rev Bras Cir Cabeça Pescoço [Internet]. 2007 [cited 2018 jul. 05];36(2):108-15. Available from: http://www.sbccp.org.br/wp-content/uploads/2014/11/2007_362-108-115.pdf

9. Botega NJ, Pondé MP, Medeiros P, Lima MG, Guerreiro CAM. Validação da Escala Hospitalar de Ansiedade e Depressão (HAD) em pacientes epilépticos ambulatoriais. J Bras Psiquiatr [Internet]. 1998 [citado 2018 jul. 05];47(6):285-9. Disponível: http://psycnet.apa.org/ record/1998-10557-001

10. Hortense FTP, Bergerot CD, Domenico EBL. Construction and validation of clinical contents for development of learning objects. Rev Bras Enferm. 2018;71(2). DOI: http://dx.doi.org/10.1590/0034-7167-2016-0622

11. Brasil. Ministério da Saúde; Conselho Nacional de Saúde. Resolução n. 466, de 12 de dezembro de 2012. Dispõe sobre diretrizes e normas regulamentadoras de pesquisas envolvendo seres humanos [Internet]. Brasília; 2012 [citado 2018 jul. 05]. Disponível em: https://bvsms. saude.gov.br/bvs/saudelegis/cns/2013/res0466_12_12_2012.html

12. Associação Brasileira de Empresas de Pesquisa. Critério Brasil 2015 e atualização da distribuição de classes para 2016 [Internet]. 2016 [citado 2018 jul. 05] São Paulo: ABEP. Disponível em: http://www.abep.org/criterio-brasil

13. Carlson RW, Nardi E, Bacigalupo J, Darlow S, McClure JS, Pfister D. NCCN framework for resource stratification: a framework for providing and improving global quality oncology care. J Natl Compr Canc Netw. 2016;14(8):961-9.

14. Oliveira TR, Souza JR. Avaliação do impacto psicossocial do diagnóstico e tratamento do câncer na vida de familiares cuidadores de pacientes em regime de internação hospitalar. Tempus, Actas Saúde Colet [Internet]. 2017 [citado 2018 jul. 05]; 11(1):215-27. Disponível em: http://docs.bvsalud.org/biblioref/2018/03/880750/lgbt-11-portug.pdf

15. Boing AF, Antunes JL. Condições socioeconômicas e câncer de cabeça e pescoço: uma revisão sistemática de literatura. Ciênc Saúde Coletiva. 2011;16(2):615-22. DOI: 10.1590/S1413-81232011000200025

16. Felippu AWD, Freire EC, Silva RA, Guimarães AV, Dedivitis RA. Impact of delay in the diagnosis and treatment of head and neck cancer. Braz J Otorhinolaryngol. 2016;82(2):140-3. DOI: http://dx.doi.org/10.1016/j.bjorl.2015.10.009

17. Peteet JR, Balboni MJ. Spirituality and religion in oncology. CA Cancer J Clin. 2013;63(4):280-9. DOI: 10.3322/caac.21187

18. Hortense FTP, Carmagnani MI, Bretas AC. O significado do tabagismo no contexto do câncer de laringe. Rev Bras Enferm. 2008;61(1):2430. DOI: http://dx.doi.org/ 10.1590/S0034-71672008000100004

19. Brucker PS, Yost K, Cashy J, Webster K, Cella D. General population and cancer patient norms for the Functional Assessment of Cancer Therapy-General (FACT-G). Eval Health Prof. 2005;28(2):192-211. DOI: https://doi.org/10.1177/0163278705275341

20. Miotto AP, Parente J. Antecedents and consequences of household financial management in Brazilian lower-middle-class. Rev Admin Empr 2015;55(1):50-64. DOI: http://dx.doi.org/10.1590/S0034-759020150106

21. Murphy BA, Deng J. Advances in supportive care for late effects of head and neck cancer. J Clin Oncol. 2015;33(29):3314-21. DOI: 10.1200/JCO.2015.61.3836

22. Brintzenhofe-Szoc KM, Levin TT, Li Y, Kissane DW, Zabora JR. Mixed anxiety/depression symptoms in a large cancer cohort: prevalence by cancer type. Psychosomatics. 2009;50(4):383-91. DOI: 10.1176/appi.psy.50.4.383

23. Bergerot CD, Laros JA, de Araujo TC. Avaliação de ansiedade e depressão em pacientes oncológicos: comparação psicométrica. Psico USF. 2014;19(2):187-97. DOI: http://dx.doi.org/10.1590/1413-82712014019002004

Fundação de Amparo à Pesquisa do Estado de São Paulo (FAPESP). Process no. 2015/09139-7. 